\title{
An Evaluation of the English Translations of Some Grammatical Patterns in the Noble Qur'ān
}

\author{
Ali Alizadeh and Taher Jahanjouyan
}

\begin{abstract}
Evaluating the translations of the Qur'ān can be an effective way of improving the quality of its translations. Having such a goal in mind, the present researchers have pinpointed the English translations of four syntactic patterns in the Qur'ān. The corpus of the study includes the translations by two British translators of the Qur'ān, Arberry (1955) and Pickthall (1930), and two Iranian translators i.e. Saffarzadeh (2007) and Iranpanah (1380). The study enjoys a descriptive-analytic methodology and has adopted a traditional approach to source text syntactic analysis. Finally, a comparison is made between the translations of the two groups of the translators qualitatively and quantitatively followed by an elaboration on the types and origins of the mistranslations.
\end{abstract}

Index Terms-Evaluation, Qur'ān translation, syntactic pattern.

\section{INTRODUCTION}

Unless the translators of the Qur'ān recognize the exact syntactic function of the Qur'ānic structures, they would not be able to translate them adequately. Moreover as Robinson proposes analyzing the source text's syntax and semantics makes you sure to know in detail what it is saying, what it is not saying, and what it is implying [1]. Based on this fact, in the present article some of the syntactic patterns of the Qur'ān which are misunderstood and mistranslated by the translators are examined using a descriptive-analytical approach to the evaluation of the Qur'ānic syntactic structures. The source text patterns that are examined in the present study are apposition, negative maker "ما", prepositional phrase, and atf or coordinating conjunction. This study tries to make it obvious how the syntactic delicacies of the Qur'ānic Arabic can lead to misunderstandings in the source text syntactic functions which can ultimately result in mistranslations of the source text.

\section{LITERATURE REVIEW}

The translations of the grammatical patterns of the Qur'ān have been examined in different articles and book-length studies. Kariminia's influential study The Syntactic Structures of Persian and the Problem of the Qur'ān Translation consists of sixteen articles in which the translations of syntactic structures of the Qur'ān are

Manuscript received March 13, 2014; revised June 30, 2015.

Ali Alizadeh is with the Ferdowsi University of Mashhad, Iran (e-mail: a.alizadeh@um.ac.ir).

Taher Jahanjouyan is with the University of Birjand, Iran (e-mail: Tjahanjou@gmail.com). investigated directly and indirectly in some parts of the given articles of the collection [2]. He provides an analytical scrutiny of different problems in translating the Qur'ān into Persian and the problems associated with it among which the evaluations of different syntactic problems are eminent.

While regarding syntax a good means of judging different translations, Āseh deals with five syntactic problematic categories in the translations of the Qur'ān [3]. The structures studied by him include words with unknown īrāb, different meanings of the preposition bā, structures starting with innámā (indeed), tádmīn (or implication), syntactic meaning, and finally syntactic differences of similar verses.

In an independent work, Gholizadeh investigates maf'ūlon-Bihi and suggests that studying the rhetorical aspects of the maf'ülon-bihi syntactically and semantically is a step towards reaching a syntactically and rhetorically qualified translations of the Qur'ān [4]. Using examples from Persian and English translations of the Qur'ān and providing linguistic and cultural reasons for showing the syntactic implication of the subject, Mansouri maintains that in some cases it is required by linguistic features and thematic necessities of the languages involved [5]. Based on his idea, subjective pronouns of the ST can be explicitated in translation.

The translation of syntactic structures of the Qur'ān is discussed by Rasoulnia and Aghajani too [6]. Negligence of the exact meaning of the conditional conjunctions, displacing the main and subordinate clauses, carelessness regarding the type and number of main and subordinate clauses, inconsistency in translating the tense of the conditional verbs and the elliptical components of them make the translators unable to render such features adequately [6]. Two background articles on the literature of the present study have just investigated the very single syntactic structures of the Qur'ān i.e. "Reflections on the Translations of the Verbs kādá, yákādū, lā yákād and lám yákod in Translations of the Qur'ān" [7]; and "Reflections on Translating the Syntactic Structure ' $m \bar{a}$ kāná li yáf'ál' and its Translations into Persian" [8] by Āseh. In 'Loss and Gain and Translation Strategies with Reference to the Translations of the Glorious Qur'ān' [9], As-Safi devotes seven pages to the syntactic level of translating the Qur'ān and proposes that "On the syntactic level, the discrepant systems of English and Arabic generate loss which necessitates compensatory strategies to help the translator to look for functional rather than formal equivalence" [9]. However, the samples examined in the present work are far from being a functional equivalent for the source text syntactic patterns and overlap with the borders of error. In this section, the source text samples as well as their target text counterparts are examined. The syntactic 
patterns investigated include apposition, negative maker "ما", resulting clause in the conditionals, prepositional phrase, coordinating conjunction and the subject.

\section{The TrAnsLAtion OF APPOSITION}

In Apposition which is known as badal (بدل) in traditional Arabic grammar, two nouns are placed side by side, both with the same syntactic function. The two nouns must have the same case ending (grammatical case). In the verse (96:16) below, the noun نَاصِيَّة is an opposition (badal) to nouns have the same case ending and are in the genitive case majrūr (مجرور). The first noun بِالنَّاصِيَّة is in the genitive case because of a prefixed preposition. The same case ending applies to the second one since the two nouns are in apposition:

$$
\text { نَاصِيَةٍة كَاذِبَة خَاطِنَة (العلق: } 1 \text { ( ) }
$$

To make the problem with the identification of the function of such a syntactic structure in the Qur'ān clearer, consider the $7^{\text {th }}$ verse of the ST in the first chapter of the Qur'ān and the translations of the given pattern shown in Table I below:

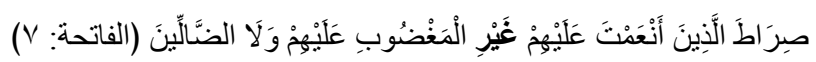

TABLE I: FOUR TRANSLATIONS OF ( $\vee$ الفاتحة)

Pickthall: The path of those whom Thou hast favoured; Not the (path) of those who earn Thine anger nor of those who go astray.

Arberry: The path of those whom Thou hast blessed, not of those against whom Thou art wrathful, nor of those who are astray

Saffarzadeh: The path of those upon whom you Bestowed the blessing [of salvation], not [The path] of those [who due to their Denial of the Truth] were inflicted by Your Wrathnor those gone astray.

Iranpanah: The Way of those on whom Thou hast bestowed Thy Grace; (Those) whose portion is not wrath and who go not astray.

In the above verse غَيْرِ which is in the genitive case or májrūr is an opposition for الَّنِينَ or for the pronoun in [10] a fact that can easily be recognized in the syntactic Fig. 1 below:

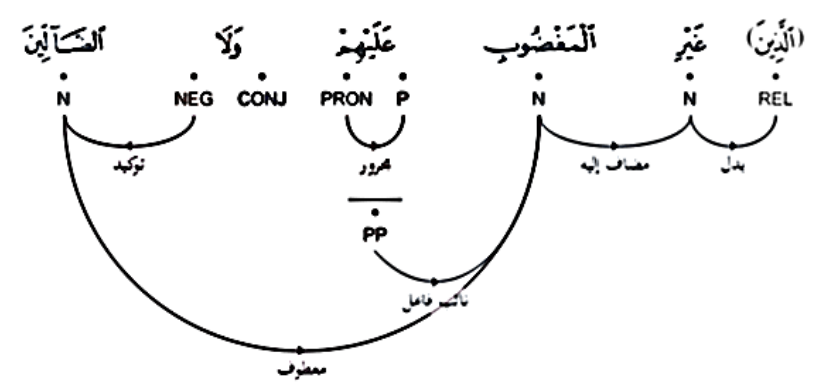

Fig. 1. Syntactic structure of ( الفاتحة:

However, a glance at the translations reveals that it is only in Iranpanah's translation of this syntactic function that the syntactic pattern is acceptably fully recognized, taken into consideration and acceptably reflected in the TT. As it can be seen in Fig. 2 below, all the relative clauses must be rendered so as they modify 'those' or stand as appositive for it:

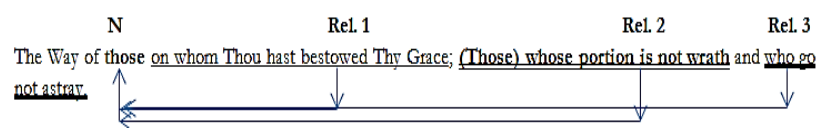

Fig. 2. Syntactive structure of English translation of (الفاتحة: $\vee$ الفان.).

Such a reproduction of ST syntactic pattern can only be seen in Iranpanah's translation. The other three translators have not recognized the function of the 'غير' so they have yielded a non-equivalent rendering of the ST. In other words, in all of the three translations the appositive phrase is taken as the appositive for 'صصرَاطَ' not for 'الَّنِينَ'. An appropriate rendering of the ST can also be seen in Irving's translation [11] of the verse:

"The road of those whom you have favored, with whom you are not angry, nor who are lost!"

Another mistranslation which is concerned to translators' lack of appreciation of the appositive pattern in the ST is detectable in 48:29 as shown in Table II:

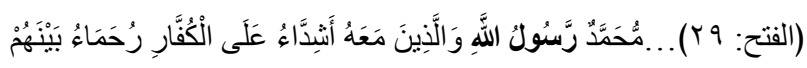

TABLE II: FOUR TRANSLATIONS OF: الفتح (rq)(

\section{Pickthall: Muhammad is the messenger of Allah. And those}

with him are hard against the disbelievers and merciful among themselves.

Arberry: Muhammad is the Messenger of God, and those who are with him are hard against the unbelievers, merciful one to another.

Saffarzadeh: Mohammad is the Messenger of Allah And his followers are stern and hard Against the disbelievers but kind and Compassionate to each other.

Iranpanah: Muhammad is the Messenger of Allah, and those who are with him are hard against the unbelievers, merciful one to another.

In most of the translations of the first part of the verse رَّسُونُ اللَّهِ mobtádā and رََُّونُ اللَّهُ as the predicate or khábár. Thus, they have translated this part of the verse as 'Muhammad is the messenger of Allah' or 'Muhammad is the Messenger of God'. The problem is that after the Great Victory, as promised by God to the Prophet, there was no doubt that the prophet was the Messenger of God. So, the question is that what can be the intended message of this verse after years of the messenger's Prophethood is confirmed under the name of Muhammad? As a result, رَّسُولُ الَّهِ is not the predicate or khábár in the above verse. In fact, the syntactic function of رَّسُولُ اللَِّّ

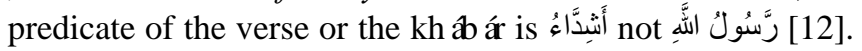
Tabarsī has mistranslated this verse, whereas the syntactic analysis provided by him confirms the translation of this verse as the present project puts it. He says [13]:

$$
\text { محمد (ص) مبتدا و رسول الله عطف بيان و الذين معه عطف على على محمد و " مليه. }
$$

Based on these facts, an acceptable translation of the first part of present verse is one in which رَسَّولُ الَّهِ is syntactically 
used as a non-defining phrase or appositive referring to محمد as it can be found in the following translation by Qarāi [14]:

"Muhammad, the apostle of Allah, and those who are with him are hard against the faithless and merciful amongst themselves."

None of the four translations is acceptable due to such a misunderstanding of syntactic pattern of the given appositive in the verse.

\section{TRANSLAtion of Prepositional Phrase}

The next problematic rendering presented in Table III is identified in translating the prepositional phrase pattern in the chapter Quraish. In the given chapter, God orders the Quraish to obey Him, in order for Him to make them unified and consolidated:

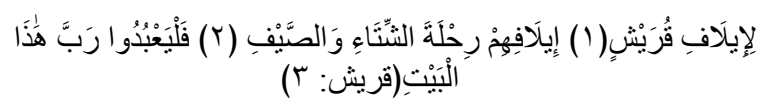

TABLE III: FouR TRANSLATIONS OF ( (قريش)

Pickthall: For the taming of Qureysh. For their taming (We cause) the caravans to set forth in winter and summer. So let them worship the Lord of this House,

Arberry: For the composing of Koraish, their composing for the winter and summer caravan! So let them serve the Lord of this House.

Saffarzadeh: The Tribe of Quraish to render their Gratitude to their Creator for their Commercial compacts with the pilgrims Of $\mathrm{Ka}^{\prime} \mathrm{bah}^{1}$, And the covenants that they make on Their trade journeys in the winter [to Yaman] and in the summer [to Syria], So they should worship the Owner of This Sacred House:

Iranpanāh: For the protection of Qureysh. Their protection during their trading caravans in the winter and the summer! So let them worship the Lord of this House, Who feeds them against hunger and gives them security against fear.

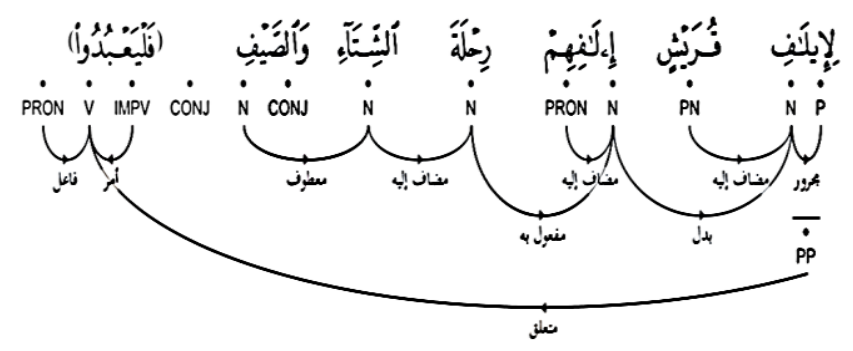

Fig. 3. Syntactic structure of ( $($ (قريش).

Different ideas are taken up by different commentators and consequently various translators regarding the لإِيَافِ قُرَيْنُ in the present verse. Even some of the commentators for justifying the interpretation they have made, has come to assert that this chapter is related to the previous chapter of the Qur'ān namely, al-Fil [15]. In his commentary, Tabātabāei [16] rejects the idea of the unity of these two chapters because there is no need to relate this chapter to the previous one to interpret it, for it is separated from the previous

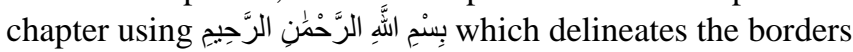
of each chapter in the Qur'ān. In this verse ' للإِيلَف

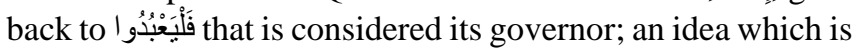

\footnotetext{
${ }^{1}$ Ilaf in this Word of Revelation means covenant and commercial compacts rather than familiarity or friendship
}

not understood appropriately by the translators mostly. The syntactic Fig. 3 has clarified such a relation:

This idea is favored by some commentators as Zamakhsharī [17] and ibn-e- Āshūr [18] and many others. Moreover, such an analysis is in accordance with the Qur'ānic syntax; as one can find many cases of the prepositional phrases used before the verb such as

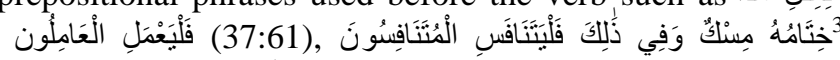

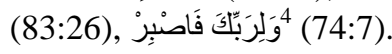

In the sample translations, just Saffarzadeh has noticed this point and a reproduction of this delicate syntactic pattern can be seen in her translation of the verse. The three other translators have not provided their readers with the present point while this patho could have been compensated and an easily-understandable version of the ST could have been produced by adding the phrase [to thank] to the first part of the first verse. To clarify the above explanations, Arberry's translation is rephrased as follows: [to thank] for the composing of Koraish, their composing for the winter and summer caravan! So let them serve the Lord of this House in which syntactic equivalence is preserved at most.

In Pickthall's translation, the additional explanatory point 'We cause', is redundant as no syntactic or even contextual clue is available to support his choice in this regard. Taking the above explanations given by syntacticians and commentators above, another acceptable translation for the verse would be the version provided by Qarāei [14]: [In gratitude] for solidarity among the Quraysh, their solidarity during winter and summer journeys, let them worship the Lord of this House.

\section{TRANSLATION OF COORDINATING CONJUNCTION}

If ma'tufon ilayh is misunderstood, it can sometimes be another cause of the production of non-equivalent translations of the ST syntactic pattern. In 8:64, there is an example of such problem in which the translation presented has ended up in an unacceptable version since the translator has not been able to decide the exact word that stands as ma'tufon ilayh. This fact is presented in Table IV below:

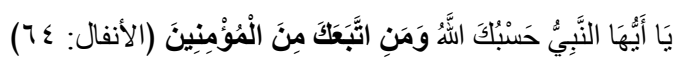

TABLE IV: FOUR TRANSLATIONS OF (الأنفال: 7 )

Pickthall: O Prophet! Allah is Sufficient for thee and those who follow thee of the believers.

Arberry: O Prophet, God suffices thee, and the believers who follow thee.

Saffarzadeh: O, Messenger! Allah will protect you And those who follow you of The believers,[against the wickedness of Your enemies]

Iranpanah: Prophet, God and the believers who follow you are sufficient support for you.

There can be two different types of syntactic analysis for the above verse. In the first analysis, و مَنِ اتَّبَحَكَ مِنَ الْمُوِْْمِنِينَ can

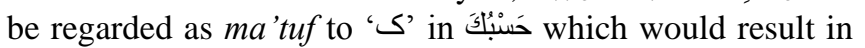
translations as provided by the first three translators,

\footnotetext{
${ }^{2}$ For the like of this, then, let the workers work.

${ }^{3}$ Whose seal is musk - for this let (all) those strive who strive for bliss -

${ }^{4}$ For the sake of thy Lord, be patient!
} 
و مَنِ انتَّعَكَكَ

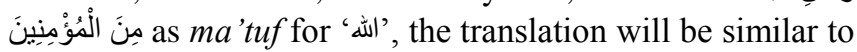
that of Iranpanah. The question is how one can give preference to one of these two groups of translations? or how can a translation be taken as acceptable and the other as problematic? For solving this problem, the researcher has used the principle of in-textual equivalence once again, i.e. using the clues available in the Qur'ān to get the exact message of the ST. In different verses of the Qur'ān as أَلَيْسن الَّهُ

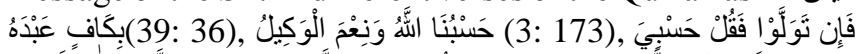

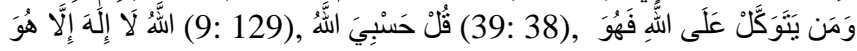
(65: 3), "the Sufficiency" is exclusively assigned to Allah.

The analysis presented by the dependency graph is also one which confirms such a Qur'ānic principle as sufficiency of Allah for his prophet and servants. In other words, such an analysis is in accordance with the first three translations. This interpretation of the verse is also in accordance with ibn-eKathīr [19]. However, the interpretation chosen by Tabātābaei [16] is one which agrees with Iranpanah's translation. But this rendering is unacceptable, because in the

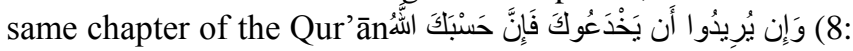
62), God attributes sufficiency to Himself again. Another instance of a problematic rendering of the ST syntactic patterns is also related to conjunctions as can be seen is the translation of 13:43 provided by the translators in Table V:

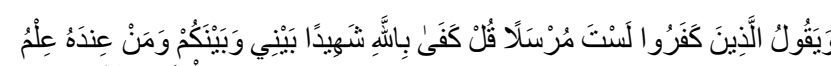

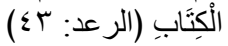

TABLE V: FOUR TRANSLATIONS OF (الر عد: 2$)$

PICKTHALL: THEY WHO DISBELIEVE SAY: THOU ART NO MESSENGER (OF ALLAH). SAY: ALLAH, AND WHOSOEVER HATH KNOWLEDGE OF THE SCRIPTURE, IS SUFFICIENT WITNESS BETWEEN ME AND YOU.

ARBERRY: THE UNBELIEVERS SAY, 'THOU ART NOT AN ENVOY.' SAY: 'GOD SUFFICES AS A WITNESS BETWEEN ME AND YOU, AND WHOSOEVER POSSESSES KNOWLEDGE OF THE BOOK.'

SAFFARZADEH: AND THE DISBELIEVERS SAY:" YOU ARE NOT A MESSENGER." SAY:" SUFFICIENT AS A WITNESS BETWEEN ME AND YOU IS ALLAH AND ALSO WITNESSING OF THOSE WHO HAVE KNOWLEDGE OF THE BOOK.

IRANPANĀH: THE UNBELIEVERS SAY: YOU ARE NOT A MESSENGER (OF ALLAH). SAY: ALLAH AND WHOSOEVER POSSESSES KNOWLEDGE OF THE SCRIPTURE, IS SUFFICIENT AS A WITNESS BETWEEN ME AND YOU.

In the above verse, the phrase وَمَنْ عِنَدُ عِلْمُ الْكِتَابِ is a relative noun in Arabic, so it is correlated to 'الهُ suggestions are made by the commentators about the syntactic analysis and message of the latter part of the verse,

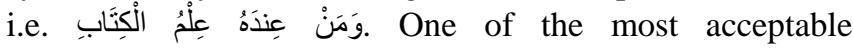
commentaries regarding the interpretation of this part of the verse is that it refers to the people of the Book or the Jews and Christians [16]. Such a commentary forms the bases for almost all of the above translations whereas there are other likely interpretations of the verse in different commentaries of the Qur'ān.

Tabarī [20] quotes Abdullah ibn-e- Salām, one of the Jewish scholars contemporary with the Prophet, saying: ' فنزل فى: قل كفى باله شهيدا بينى و بينكم و من عنده علم الكتاب , which means "Enough for a witness between me and you is Allah, as well as those who have knowledge of the Book are revealed concerning me".
However, the only problematic translation from among the translations is that of Arberry. In his translation, the meaning of the verse is distorted and the message cannot be understood as expressed by the verse since the phraseology of the ST has been preserved. To put it another way, the verse says that God recommends that his Prophet suffice to the witnessing of His, the Jews and Christians as the proof of his Prophet hood due to the fact that their religious scholars knew the Prophet and his characteristics were given in their religious sources 5 . Thus, the translator could have chosen, as the other translators have, a suitable rephrasing or restructuring for it which could easily convey such a meaning, whereas sticking to the ST syntax has hindered such an easy, appropriate rendering of the ST. Here is another example of the mistranslation of the coordinating conjunction.The translations are presented in Table VI:

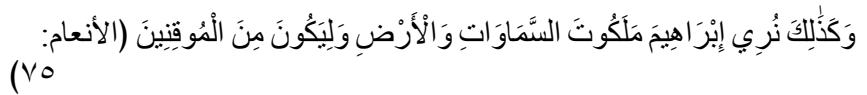

TABLE VI: FouR TRANSLATIONS OF(V0:الانعام)

Pickthall: Thus did We show Abraham the kingdom of the heavens and the earth that he might be of those possessing certainty:

Arberry: So We were showing Abraham the kingdom of the heavens and earth, that he might be of those having sure faith.

Saffarzadeh: And thus, We showed Ibrahim The Dominion System of the heavens And the earth, so that he might attain Certitude [through gaining the knowledge Of observation];

Iranpanah: And thus We showed Abraham the kingdom of the heavens and the earth and that he might be of those who are sure.

The problem that is detected in the translations of the

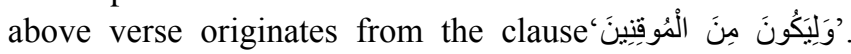
Tabātabaei [16] takes a clause to be omitted from this

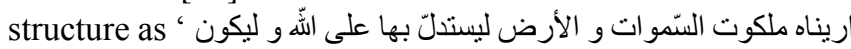

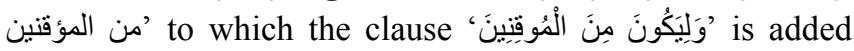
using a coordinating conjunction. Tabatabaei [16] also regards 'ليكون كذا و كذا و ليكون من الموقنين' to be omitted before the sentence starting with ' $و$ '.

Syntactician like Sāfi [12] and Ukbarī [21] rephrase such an omitted component as 'ليستدلّ و ليكون من الموقنين'. Darvīsh [22] gives his account on the verse similar to the above commentators and syntacticians as الواو عاطفة، و المعطوف محذوف، أي: و فعلنا ذلك ليكون.

In his seminal book on Arabic syntax, Al-Moqnī al-Labīb, Ibn-e- Hisham divides ' $g$ ' into fifteen categories in Arabic [23] among which is the redundant or al-zāyed ' $g$ '. The eighth type of ' $g$ ' in his classification is a kind whose existence or non-existence is the same ${ }^{6}$. Based on these facts, this conjunction can either be translated as 'that' or 'so that' like the rendering given by Pickthall, Arberry and Saffarzadeh or as a translation in which the omitted components are explicitated. Therefore, if such a strategy is followed as by the aforementioned translators, the translation of such a pattern will no more be problematic. In the translation provided by Iranpanah, this conjunction is rendered into its English counterpart whereas rendering it has

\footnotetext{
${ }^{5}$ Cf. Qur'ān (2:146): Those unto whom We gave the Scripture recognize (this revelation) as they recognize their sons. But lo! a party of them knowingly conceal the truth.

${ }^{6}$ Other instances of such ' 9 ' can be found in verses $2: 185 ; 3: 166 ; 7$ : $174 ; 6: 75 ; 37: 103-104 ; 6: 92$ and so on.
} 
kept the smooth fluency of the translation. His translation would have read more natural in English if he had not translated the given conjunction, because 'that' conveys the aimed meaning of the ST sufficiently.

A restructuring of the verse is presented below using the omitted components of ST in brackets:

"And such we showed Abraham the Dominion of the heavens and the earth [so that he reflect on it] and be of those who possess certitude."

\section{The REsults}

In the present section, the results obtained after examining the mistranslations in some of the ST syntactic structures are presented for each individual translator summarily using qualitative and quantitative data followed by an analysis of the probable origins of the pathos identified in each of the translations. There are about four acceptable renderings Pickthall's translations of the samples scrutinized. In his translations of the chosen verses, the number of acceptable renderings of the chosen syntactic structures is equal to those of the problematic ones. There is also a case of reductionist translation in Pickthall's renderings the reason for which can be different possible readings of the ST syntactic structure. In other words, it could be read or syntactically analyzed in different ways resulting in different renderings. But the fact is that adopting a certain reading of the ST reduces the possibility of transferring the other meanings. A new problem identified in his translation is that of problematic modification. This term is used here to refer to the change of the modifier of a noun and moving its modifier erroneously to modify another noun, e.g. in 1.7.

The origins of the pathos in five cases out of 6 , i.e. $83.33 \%$ go back to ST syntactic complexity and only in one instance it is likely to be rooted in translator's competence or lack of focused scrutiny of ST during analysis. Although the number of acceptable renderings is the same for Arberry and Iranpanah, in the case of the former translator one instance of ambiguous TT, 13:43, has added a different sort of problem to his translation which does not exist in Pickthall's rendering.

The sources of the problems are also the same as those of Pickthall, namely just one of the problems is translator-oriented (13:43), where the translator could have kept the ambiguous TT by changing the phraseology of his chosen equivalents. Saffarzadeh's translations of the chosen patterns has yielded the highest number of non-erroneous renderings which amounts to 5, while the number of non-problematic renderings is four in both Pickthall's and Arberry's translations and are consequently reduced to two in Iranpanah's renderings. Out of the five instances of problematic translations, just in one of them the non-equivalent rendering seems to be a result of translator's inconsideration by Saffarzadeh. In other cases, it can be just a consequence of ST syntactic complexity.

As there were one case of problematic modification and reductionism in Arberry's and Pickthall's translations of the syntactic patterns, they have the same frequency in Saffarzadeh's translations. The highest number of problematic or non-equivalent renderings which is about 6 out of 10 is spotted in Iranpanah's translation. Only two of his translations are acceptable while the two remaining ones are either a case of total non-equivalence or reductionist TT. The origins of two of his pathologic renderings by Iranpanah pertained to the inconsideration of ST syntactic elements by the translator, while in other 6 cases the patho might have been rooted in ST syntactic patterns complexity.

Although Iranpanah is widely influenced by Arberry, the problems of his translations are less varied than those identified in Arberry's translation.

However, the number of mistranslations by him is twice as many as the number of problems in Arberry's renderings. While referring to the origins of the problematic renderings, the detailed reference to each of the subcategories of them are avoided and the two general categories translatorial and textual origins are adopted by the researchers to point to the probable origins of the pathos. The given problems have two origins which are either text-based or translatorial. Generally, the text-based or translator-based origins for the pathos of translating the Qur'ān might have different sub-categories leading the translators to translate the ST syntactic structures pathologically. So, the text-based origins or the textual origins of pathos might be the level of readability of ST syntactic structures, the ambiguity of ST syntactic structures, the various and complex syntactic parsing for the same verse, different readings of the ST segment, the authority of Islamic narratives which leads to an especial syntactic analysis though against the ST linguistic requirements, change of the authoritative ST etc. In the same way, the translatorial origins for the problems might be the lack of enough consideration by the translator, his ideological stance, the translators' weak background in Arabic or English, the translators' passive agency, and weak level of translational competence and so on. In some of the cases, due to the blurry borders between the textual considerations and translatorial origins of the pathos under the impact of which the pathos might have occurred, we have referred to both of them as the factors resulting in the pathologic TT for a given syntactic structure. Totally, 95\% of the total number of problems detected in the above syntactic structures is a result of textual difficulties to which $5 \%$ of translatorial origins can be added.

\section{CONCLUSION}

As it can be seen, the number of the mistranslations is the same for Pickthall and Saffarzadeh. However, the highest number of translationese in translating the syntactic patterns is committed by Arberry and Iranpanah. The high rate of the mistranslations by Iranpanah might be attributed to his lack of adequate competence and understanding of Arabic. Moreover, as his translation shows, he is influenced by Arberry and seems not to have the independence in doing his translation as Pickthall and Saffarzadeh since Pickthall's translation historically precedes all of the above translations. Moreover, Saffarzadeh has been an expert in translation theory and has her unique explanatory method of translating the Qur'ān. Additionally, Arberry's mastery on Arabic, though in contrast with his expertise in Arabic, can be called 
'immediate lapses' which are further repeated and increased in Iranpanah's translation once again.

\section{REFERENCES}

[1] D. Robinson, Becoming a Translator, $2^{\text {nd }}$ ed., New York, Routledge: London, 2007.

[2] M. Kariminia, The Syntactic Structures of Persian and the Problem of the Qur'ān Translation, Tehran: Hermes, 1389.

[3] J. A Aseh, "A criticism of the Qur'ān translations from the point of view of syntax," Tarjumān-e Vahy, vol. 14, no. 1. pp. 4-23, October 2010.

[4] H. Gholizadeh, "The position of syntactico-rhetorical structure of Maf'ūlon-Béh in translations of the Qur'ān," Faslnameye Pazhuheshhaye Qur'āni, Autumn \& Winter, no. 59-60, 1388.

[5] M. Mansouri, "A study on the hidden subjective pronouns in English and Persian translations of the holy Qur'ān," Translation Studies, vol. 7 , no. 26. pp. 63-80, Summer 1388.

[6] M. Mansouri, "A Study on the hidden subjective pronouns in English and Persian translations of the holy Qur'ān," Translation Studies, vol. 7, no. 26. pp. 63-80, Summer 1388 .

[7] J. Āseh, "Reflections on the translations of the verbs Kādá, Yákādū, LāYákād and LámYákod in translations of the Qur'ān," Ma'refat, Mordād, vol. 20, no. 164, pp. 71-82, 1390.

[8] J. Āseh, "Reflections on translating the syntactic structure 'MāKāná li Yáfál' and its translations into Persian," Tarjumān-E Vahy, vol. 15, no. 29. pp. 54-68, 1390.

[9] A. B. As-Sāfí. (August 2012). Loss and gain and translation strategies with reference to the translations of the glorious Qur'ān. [Online]. Available:

https://www.uop.edu.jo/download/Research/.../424_2060_A.B

[10] A. H. Āmelī, "Al-Wajiz fi Tafsīr al-Qur'ān al-Azīz (The Brief Commentary of the Holy Quran)," Qom: Dār al-The Qur'ān al-Karim, vol. 3,1413 .

[11] T. B. Irving, The Qur'ann: The First American Version, Vermont: Brattleboro, 1985.

[12] M. Sāfī, "Aljadval fi îrāb al-koran (the syntax of the holy Qur'an)," Beirut: Dar al-Rashīd, vol. 1, no. 7, pp. 26-30, 1995.

[13] F. H. Tabarsī, "Majma' al-bayān fi tafsīr al-Qur'Ān (the elucidation of the exegesis of the Qur'an)," Tehran: Entesharat-e-Nāser Khosrow, vol. 4, no. 6, pp. 26, 1372.

[14] A. Q. Qarāī, The Qur'ān: With a Phrase by Phrase English Translation, $2^{\text {nd }}$ ed., London: ICAS Press, 2005.
[15] A. M. A. Dakhīl, "Al-wajiz fi tafsīr al-kitāb al-Azīz (the brief commentary of he noble Qur'an)," Dār al-Ta'âruflilMatbu'àt, vol. 1, 1422 .

[16] M. H. Tabātabāei, "Tafsir of al-mizān (al-mizan exegisis of the Qur'an)," Qom: Daftar-e-Entesharat-e-Eslami-e-Jāme'eye Modarresin-e-Hozeye Elmiyye Qom, vol. 7, no. 9, pp. 11, 18-20, 1417.

[17] M. Zamakhsharī, "Al-kashshāfan haqāiq qavamez al-tanzil (the discoverer of revealed truths of the Qur'an)," Dār al-Kitab al-Arabi, vol. 2 , no. 4,1407

[18] M. I. Āshūr, "Altahrīr wa al-tanwir (liberation and enlightenment: a commentary on the Qur'an)," Tunis: Al-Dār Tunesiyyalil Nashr, vol. 6, no. 30, 1984.

[19] E. A. I. Kathīr, "Tafsīr al-qur'ān al-azīm (the exegesis of the great Qur'an)," Beirut: Dār al-Kutub al-Ilmīyya, vol. 4, no. 6, 1419.

[20] A. M. J. Tabarī, "Jāmi al-bayān fi tafsir al-qur'ān (the unabrighed commentary on the Qur'an)," Beirut: Dār al-Ma'rifah, vol. 13, 1412.

[21] A. Ukbarī, "Al-tebyān fi īrāb al-qur'ān (an explanation of the syntax of the Qur'an)," Oman \& Riyadh: Beit al-Afkär Alduvaliyyah, 1796.

[22] M. Darvīsh, "Ī̄āab al-koran wa Bayānuh (the illumination of the Qur'an syntax)," Syria: Dār Al-Ershäd, vol. 1, no. 3, 1415.

[23] A. I. Hishām, "Moqnī al-labīb án kutub-al-a'áārīb (the compreensive syntax of Qur'anic arabic)," Beirut: Dār al-Fikrlil-Tebāátva-al-NashrvaTozī', 1992.

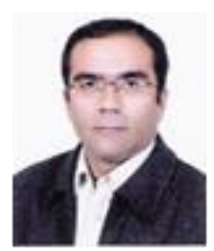

Ali Alizadeh is an associate professor of linguistics in Ferdowsi University of Mashhad, Iran. He has been teaching linguistic courses in different universities for twenty years. His main areas of interest are syntax particularly Persian syntax and semantics intercourse. He has published a couple of papers in scientific journals and participated in different international conferences on linguistics and language studies.

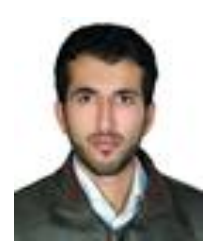

Taher Jahanjouyan was born on May 12, 1988 in Astara, Iran. He has an M.A. in translation studies from University of Birjand, Iran and has the experience of teaching English for ten years. He has published a number of papers in Iranian and international conferences. His areas of interest include translation studies, arabic linguistics, translation criticism, quranic studies and research methodology. He has also coauthored two papers on the evaluation of the English translations of the Qur'an published in Journal of Translation Studies and Journal of Subcontinent Studies. 